\title{
Analisis Kemampuan Metakognisi Siswa dalam Pemecahan Masalah Menggunakan Soal TIMSS ditinjau dari Perbedaan Gender
}

\author{
Siti Nur Fatima ${ }^{1 *}$, Zainul Munawwir ${ }^{2}$, Lisma Dian Kartika Sari ${ }^{3}$ \\ 1, 2,3 Program Studi Pendidikan Matematika, STKIP PGRI Situbondo, Indonesia \\ *email: fatims21101998@ gmail.com
}

\begin{abstract}
Seeing the differences in the results of several previous studies on metacognitive abilities in problem solving, researchers are interested in examining students' metacognitive abilities in problem solving in terms of gender differences. This problem is important to study because it aims to determine the implementation of the metacognitive abilities of male and female students in problem solvingThe purpose of this study was to determine the metacognitive ability of male and female students in problem solving using TIMSS questions at SMP Al-Falah Pesanggrahan Jangkar for the 2020/2021 academic year. This type of research is descriptive qualitative. The subjects of this study were one male student and one female student from class VII SMP AL-Falah Pesanggrahan who had the same mathematical ability. Data collection techniques in this study were interviews, mathematical ability tests and TIMSS questions. Data analysis in this study was analyzed on each data collection technique. The results of data analysis showed that there was no difference in metacognitive ability in problem solving between male and female students. The metacognitive abilities of male and female students have been used well in problem solving. Both of them can explain their thinking process in every stage of problem solving.
\end{abstract}

Keywords: Metacognition Ability, Problem solving, TIMSS questions, Mathematical Ability, Gender Difference.

\begin{abstract}
Abstrak:Melihat perbedaan hasil dari beberapa penelitian sebelumnya tentang kemampuan metakognisi dalam pemecahan masalah, peneliti tertarik untuk meneliti kemampuan metakognisi siswa dalam pemecahan masalah ditinjau dari perbedaan gender. Permasalahan tersebut menjadi penting untuk diteliti karena bertujuan untuk mengetahui terlaksana kemampuan metakognisi yang dimiliki siswa laki-laki dan siswa perempuan dalam pemecahan masalah.Tujuan penelitian ini adalah untuk mengetahui kemampuan metakognisi siswa laki-laki dan siswa perempuan dalam pemecahan masalah menggunakan soal TIMSS di SMP Al-Falah Pesanggrahan Jangkar Tahun Pelajaran 2020/2021. Jenis penelitian ini adalah deskriptif kualitatif. Subjek penelitian ini adalah satu orang siswa laki-laki dan satu orang siswa perempuan dari kelas VII SMP AL-Falah Pesanggrahan yang memiliki kemampuan matematika sama. Teknik pengumpulan data dalam penelitian ini adalah wawancara, tes kemamuan matematika dan soal TIMSS. Analisis data dalam penelitian ini dianalisis pada setiap teknik pengumpulan data. Hasil analisis data menunjukkan bahwa tidak ada perbedaan kemampuan metakognisi dalam pemecahan masalah antara siswa lakilaki dan siswa perempuan. Kemampuan metakognisi siswa laki-laki dan siswa perempuan telah digunakan dengan baik dalam pemecahan masalah. Keduanya sama-sama dapat menjelaskan proses berpikirnya dalam setiap tahap pemecahan masalah.
\end{abstract}

Kata kunci: Kemampuan Metakognisi, Pemecahan Masalah, Soal TIMSS, Kemampuan Matematika, Perbedaan Gender

Copyright (c) 2021 The Authors. This is an open access article under the CC BY-SA 4.0 license (https://creativecommons.org/licenses/by-sa/4.0/) 


\section{PENDAHULUAN}

Belajar matematika merupakan proses berpikir dalam menyusuninformasi-informasi yang diperoleh, menyimpan dan menyajikan kembali. Hal ini dikenal dengan aktivitas kognisi. Kognisi merupakan kata kerja yang menunjukkan suatu proses berpikir (Chairani,

2016). Dalam proses berpikir tentunya terdapat cara manusia berpikir. Pemahaman terhadap cara berpikir tersebut disebut metakognisi.

Anggo (2014) menyatakan bahwa metakognisi merupakan kesadaran terhadap proses berpikir dalam hal merencanakan, kemampuan memantau, kemampuan mengatur dan mengevaluasi proses dan hasil berpikir siswa pada saat memecahkan masalah matematika. Berdasarkan pendapat tersebut, maka metakognisi dapat diartikan sebagai proses memahami dan memantau kegiatan berpikir.

Metakognisi memiliki peran penting untuk mendukung kesuksesansiswa dalam pemecahan masalah matematika. Hal ini sesuai dengan pernyataan Jianto (2020) bahwa kemampuan metakognisi adalah kemampuan seseorang untuk mereview, memantau dan memonitor proses solusi di dalampemecahan masalah. Kemampuan metakognisi erat hubungannya dengan kemampuan pemecahan masalah. Keduanya saling berkaitan, salah satu contoh dalam proses pemecahan masalah misalnya pada tahap memahami masalah maka proses metakognisi yang yang terjadi adalah bagaimana cara kita memahami masalah, mengapa kita memilih cara tesebut, bagaimana cara kita mengidentifikasi data saat memahami masalah dan mengapa kita tidak menggunakan cara lain selain rencana yang telah kita buat. Hal ini menunjukkan bahwa dalam pemecahan masalah dibutuhkan kemampuan metakognisi.

Berdasarkan pernyataan di atas, peneliti tertarik untuk menganalisis terlaksananya kemampuan metakognisi siswa dalam pemecahan masalah.Karena melihat hubungan antara keduanya sangat berkaitan sebagaimana yang telah dipaparkan sebelumnya, membuat penulis ingin melihat langsung bagaimana teori tersebut dilapangan. Untuk mengetahui kemampuan metakognisi peserta didik dalam pemecahan masalah dapat kita lihat dari proses peserta didik dalam menyelesaikan soal pemecahan masalah, misalnya soal-soal TIMSS. Hal ini sejalan dengan pendapat Utami \& Wutsqa (2017) yang menyatakan bahwa Salah satu hasil tes yang mengukurkemampuan pemecahan masalah siswa dapatdilihat dari hasil tes yang dilakukan oleh duastudi internasional, yaitu Programme forInternational Student Assesment (PISA) danTrends in International Mathematics andScience Study (TIMSS). TIMSSmerupakan studilintas negara yang dilaksanakan olehIEA (International Association for the Evaluation ofEducational 
Achievement) setiap empattahun sekali yang bertujuan untuk mengetahuipeningkatan pembelajaran matematika dan sainsdalam kurikulum sekolah. Berdasarkan paparan tersebut maka jelaslah bahwa soal TIMSS bisa digunakan sebagai alat untuk menganalisis kemampuan metakognisi siswa dalam pemecahan masalah matematika.

Selanjutnya kemampuan metakognisi dalam pemecahan masalah dari setiap individu tentunya berbeda, terutama apabila dilihat dari jenis kelamin yaitu laki-laki dan perempuan.Meski keduanya memiliki kemampuan pemecahan masalah yang sama tetapi akan ada perbedaan dalam proses metakognisinya hal ini karena perbedaan karakter dan pola pikir yang dimiliki.

Berdasarkan penelitian yang dilakukan oleh Khairunnisa \& Setyaningsih (2017) memperoleh hasil bahwa kemampuan metakognisi belum digunakan dengan baik oleh siswa laki-laki karena hanya memenuhi tahap perencanaan. Sedangkan siswa perempuan telah menggunakan kemampuan metakognisinya dengan baik dalam memecahkan masalah karena memenuhi tiga tahap kemampuan metakognisi. Hal ini sejalan dengan penelitian Anggraeni \& Herdiman (2018) yang menyatakan bahwa kemampuanpemecahan masalah matematika siswa perempuan lebih baik dibanding siswa laki-laki, Hal ini dikarenakan manajemen waktu siswa perempuan yang lebih baik dibandingkan siswa laki-laki. Sedangkan penelitian yang dilakukan oleh Weni (2019) memiliki kesimpulan yang berbeda dengan penelitisn tersebut yaitu menyatakan bahwa tidak ada perbedaankemampuan metakognisi antara siswa laki-lakidengan siswa perempuan, siswa laki-laki dan perempuanmemiliki karakter masing-masing untukmenemukan strategi yang tepat untukmemecahkan masalah.

Melihat perbedaan hasil dari beberapa penelitian sebelumnya sebagaimana yang telah dipaparkan, peneliti semakin tertarik untuk meneliti kemampuan metakognisi siswa dalam pemecahan masalah ditinjau dari perbedaan gender .Permasalahan tersebut menjadi penting untuk diteliti karena bertujuan untuk mengetahui terlaksana kemampuan metakognisi yang dimiliki siswa laki-laki dan siswa perempuan dalam pemecahan masalah.dengan mengetahui hal tersebut nantinya hasil penelitian ini diharapkan dapat menjadi sumber informasi dan pengetahuan yang baru bagi pembaca.

\section{METODE}

Penelitian ini adalah penelitian deskriptif kualitatif dengan pendekatan penelitian lapangan (field research). Penelitian dilakukan di SMP AL-FALAH Pesanggrahan, Kecamatan Jangkar, Kabupaten Situbondo.Teknik sampling yang digunakan dalam penelitian ini yaitu teknik purposive sampling.Siswa yang menjadi sumber data dalam penelitian ini adalah satu orang 
siswa laki-laki dan satu orang siswa perempuan dari kelas VII SMP AL-FALAH Pesanggrahan. Siswa yang dipilih sebagai subjek penelitian diasumsikan memiliki kemampuan matematis yang sama. Hal ini ditunjukkan dengan hasil tes kemampuan matematis yang menunjukkan kedua siswa tersebut memiliki nilai rata-rata tinggi dengan kesalahan yang relatif sama.

Teknik Pengumpulan data dalam penelitian ini yaitu wawancara, tes kemampuan matematika danSoal TIMSS.Instrumen penelitian yang digunakan dalam penelitian ini yaitu soal tes kemampuan matematika dan soal TIMSS.Analisis data hasil wawancara dilakukan dengan langkah-langkah yaitu reduksi data, pemaparan data dan menarik kesimpulan dan menverifikasi kesimpulan.Analisis data soal kemampuan matematika dianalisis berdasarkan ketepatan setiap langkah penyelesaian berdasarkan kunci jawaban.Analis data hasil pengerjaan soal model TIMSS dilakukan berdasarkan kebenaran penyelesaian yang dilakukan peserta didik sesuai dengan patunjuk penyelesaian.Hasil pekerjaan subjek penelitian kemudian dianalis dan disajikan dalam bentuk deskripsi yang didasarkan pada setiap tahap pemecahan masalah.Agar data yang diperoleh dapat dipertanggungjawabkan keakuratannya, maka data harus kredibel.Untuk memenuhi kriteria kredibilitas, peneliti munggunakan teknik triangulasi waktu.

\section{HASIL DAN PEMBAHASAN}

\section{Subjek Penelitian Siswa Perempuan (PR)}

Hasil analisis data dari hasil pengerjaan soal TIMSS dan wawancara menunjukkan bahwa PR telah melibatkan kemampuan metakognisinya dalam setiap langkah pemecahan masalah. Hal ini dapat dilihat pada saat wawancara PR mampu menjelaskan seluruh proses pemikirannya dalam menyelesaikan soal serta kesesuaian penjelasan PR dengan jawaban yang telah PR tulis. Selanjutnya kemampuan metakognisi PR dalam pemecahan masalah akan dibahas berdasarkan tahap-tahap pemecahan masalah yaitu sebagai berikut :

a. Memahami Masalah

Pada tahap memahami masalah PR telah berhasil memahami masalah dengan baik. Hal ini ditunjukkan dengan kebenaran hasil identifikasi permasalahan yang ditulis PR. Menurut Khairunnisa \& Setyaningsih (2017), ketika siswa sudah dapat memahami permasalahandengan baik berarti siswa sudah melibatkan metakognisisnya dalam memahami masalah. Berdasarkan pendapat tersebut, maka PR telah melibatkan kemampuan metakognisinya dalam memahami masalah.

Pada saat wawancara, PR terlihat ragu dalam menjelaskan pemahamannya terhadap soal.Keraguan PR terlihat jelas diwajahnya ketika PR menjelaskan sambil sesekali tersenyum 
dan menggelengkan kepala serta dengan posisi kepala PR menunduk. Hal ini diperkuat dengan pengakuan PR bahwa ia merasa ragu karena merasa takut salah. Keraguan PR menunjukkan bahwa PR memiliki tingkat efikasi diri yang masih rendah. Menurut Sholihah et al., (2020), seseorang dengan efikasidiri rendah cenderung menganggap dirinya tidak mampu mengerjakanpersoalan matematika karena adanyakeraguan dalam dirinya untuk mampu menyelesaikan persoalan yang dihadapi. Meski dengan penuh keraguan PR bisa menjelaskan semua pemahamannya terhadap permasalah pada soal.

PR mengatakan yang diketahui pada soal adalah jumlah kelereng Doni sebanyak 20 kelereng lebih banyak dari kelereng Andre, kelereng Andi setengah dari kelereng Doni dan jumlah semua kelereng 55 buah dan yang ditanyakan jumlah kelereng Andre dalam bentuk persen. PR mampu menjelaskan pemahamannya menggunakan bahasanya sendiri. Dalam lembar jawaban PR menulis sebagai berikut:

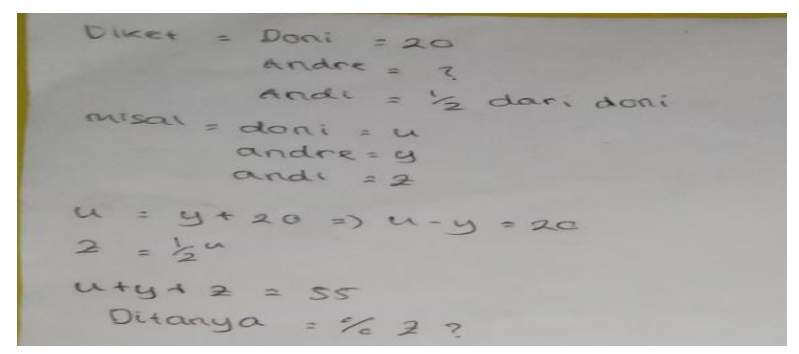

Gambar 1. Potongan Jawaban PR

Dari lembar jawaban PR pada Gambar 4.11, terlihat penulisan hasil identifikasi masih salah padahal saat PR menjelaskan sudah benar. Dari penjelasan PR menunjukkan bahwa PR telah melibatkan metakognisinya dalam memahami masalah karena ia telah memahami masalah dengan baik meski penulisannya terdapat kesalahan. Hal ini sejalan dengan pendapat Khairunnisa \& Setyaningsih (2017), ketika siswa sudah dapat memahami permasalahandengan baik berarti siswa sudah melibatkan metakognisisnya dalam memahami masalah.

Tidak hanya menjelaskan pemahamannya, PR juga menjelaskan cara yang digunakan dalam memahami masalah pada soal yaitu dengan membacanya didalam hati secara berulangulang sampai menemukan permasalahannya. Hal ini diperkuat dengan hasil pengamatan ketika PR mendapatkan soal, PR membutuhkan waktu lama untuk menuliskan hasil identifikasinya. PR telah menggunakan cara yang tepat dalam memahami masalah karena menurut Sari et al., (2016) tujuan membaca soal atau masalah adalah untuk memperoleh informasi yang dibutuhkan agar menemukan carapenyelesaian.

PR menyadari proses berpikirnya tentang cara yang digunakan dalam memahami masalah. Hal ini menunjukkan PR telah mencapai indikator metakognisi pada tahap memahami masalah 
yaitu dapat menjelaskan cara -cara yang digunakan untuk memahami masalah. Hal tersebut sejalan dengan, hasil penelitian Sudia (2014), Subjek perempuan menyadari pentingnya memikirkan cara memahami masalah, yaitu dilakukan dengan cara membaca masalah beberapa kali sampai masalah benar-benar dipahami dengan baik, Hal ini menunjukkan subjek perempuan telah melibatkan metakognisinya dalam memahami masalah.

Selanjutnya PR memberikan alasan mengapa memilih membaca sebagai cara memahami masalah yaitu karena sudah menjadi kebiasaan PR dalam memahami masalah pada setiap soal yang ia kerjakan. Hal ini menunjukkan bahwa PR telah menyadari alasan memilih cara dalam memahami masalah. Artinya PR telah mencapai indikator metakognisi dalam memahami masalah yaitu menjelaskan alasan dalam memilih cara untuk memahami masalah. Selain itu PR juga mengatakan karena cara tersebut sudah menjadi kebiasaannya, maka PR tidak memiliki cara lain. Baginya cara tersebut adalah cara yang paling tepat. Pernyataan tersebut menunjukkan PR telah menyadari tentang mengapa PR tidak menggunakan cara lain dalam memahami masalah. Hal ini menunjukkan PR telah mencapai indikator metakognisi dalam memahmi masalah yaitu dapat menjelaskan alasan mengapa tidak menggunkan cara lain dalam memahami masalah.

Setelah memahami soal, kemudian PR mengidentifiksi permasalahan dalam soal dengan cara menyimpulkan hasil pemahamannya. PR hanya menggunakan cara tersebut karena baginya jika sudah paham terhadap permasalahan pada soal maka identifikasi masalah sudah jelas terlihat dalam soal sehingga PR dengan mudah mengidentifikasi permasalahannya. Hal ini menunjukkan bahwa PR menyadari pentingnya mengetahui cara meng-identifikasi permasalahan dalam soal. Dimana hal tersebut menunjukkan bahwa PR telah mencapai indikator metakognisi dalam memahami masalah yaitu dapat menjelaskan bagaimana caranya mengidentifikasi data dalam diketahui dan ditanyakan sebagai bukti bahwa siswa telah memahami masalah.

Berdasarkan penjelasan tersebut, dapat disimpulkan bahwa PR telah mencapai semua indikator metakognisi dalam memahami masalah yang digunakan dalam penelitian ini.Sehingga PR dapat dikatakan telah melibatkan kemampuan metakognisinya dalam memahami masalah. Sejalan dengan hal tersebut, menurut Weni et al., (2019) siswa perempuan yang memiliki kemampuan metakognisi yang baik dapat menjelaskan proses memahami masalah dengan jelas dan menurut Sari et al., (2016) aktivitas metakognisi siswa perempuan dalam memahami masalah berhubungan dengan pengetahuan strategi dalam memahami masalah. 


\section{b. Merencanakan Penyelesaian}

Pada tahap merencanakan penyelesaian pemecahan masalah, PR menjelaskan dengan lancar dan dengan percaya diri bahwa dia akan menggunakan konsep Al-jabar. Adapun langkah pertama yang akan dilakukan adalah memisalkan semua yang diketahui dan yang ditanyakan kedalam variabel Al-jabar, PR memisalkan Doni $=\mathrm{u}$, Andre $=\mathrm{y}$ dan andi $=\mathrm{z}$. kemudian $\mathrm{u}=$ $\mathrm{y}+20 \rightarrow \mathrm{u}-\mathrm{y}=20, \mathrm{z}=1 / 2 \mathrm{u}$ dan $\mathrm{u}+\mathrm{y}+\mathrm{z}=55$. Adapun yang ditanyakan adalah jumlah kelereng andre $\mathrm{z}=\ldots \%$. Kemudian menjelaskan rumus dari konsep matematika yang akan PR gunakan yaitu perhitungan Al-jabar dengan rumus $\mathrm{u}+\mathrm{y}+\mathrm{z}=55$. Dan kemudian mencari persentasi jumlah kelereng Andre.

Hal tersebut menunjukkan bahwa PR sudah mampu menyajikan masalah kedalam konsep matematika, hanya saja PR lupa menyebutkan jumlah kelerang Andre yaitu y =n. pada jawaban tertulisnya-pun PR tidak menuliskannya. Dari penjelasan PR terlihat dia telah menyadari pentingnya memikirkan rencana pemecahan masalah dan memahami konsep yang akan digunakan dalam memahami masalah. Hal ini menunjukkan bahwa PR telah mencapai indikator kemampuan metakognisi dalam memikirkan rencana yaitu dapat menjelaskan konsep-konsep yang digunakan untuk menyelesaikan masalah serta langkah-langkahnya. Hal ini sejalan dengan hasil penelitian Sudia (2014), Subjek perempuan telah melibatkan metakognisinya karena telah mampu memikirkan rencana alur pemecahan masalah, memikirkan rumus dan waktu yang akan digunakan dalam memecahan masalah serta memikirkan cara memecahkan masalah.

Selanjutnya PR juga menjelaskan alasanya mengapa memilih rencana pemecahan masalah tersebut yaitu karena sesuai dengan pengetahuan dan pemahaman yang PR miliki tentang permasalahan dalam soal sehingga rencana itulah yang dipilih PR. PR juga mengatakan bahwa ia yakin rencananya akan bisa dilaksanakan dan akan mendapatkan hasil penyelesaian yang benar. Penjelasan PR menunjukkan bahwa PR menyadari tentang alasan memilih rencana dan keyakinannya terhadap rencana. Artinya PR telah mencapai indikator kemampuan metakognisi dalam memikirkan rencana pemecahan masalah yaitu dapat menjelaskan alasan dalam memilih rencana penyelesaian dan dapat menjelaskan pernyataan atau alasan tentang keyakinan dari rencana yang dibuatnya.

Berdasarkan pemaparan diatas, terlihat PR memiliki kesadaran terhadap pengetahuan yang dimiliki dan mampu mengaitkannya terhadap soal sehingnga PR mampu menuliskan serta menjelaskan langkah-langkah penyelesaian yang akan digunakan. kesadaran tersebut merupakan aktivitas metakognisi dalam merencanakan pemecahan masalah. Hal ini sejalan 
dengan pendapat Sari et al., (2016) yaitu Aktivitasmetakognisi siswa perempuan dalam tahapan menentukan rencanaadalah berhubungan dengan pengetahuan prosedural yang dimiliki siswa terhadap soal denganmengungkapkan langkah-langkah pengerjaan yang akan dilakukan dengan melihat soalyang diberikan.

Dari pemaparan diatas diperoleh kesimpulan bahwa kemampuan metakognisi PR dalam merencanakan pemecahan masalah sudah digunakan dengan baik. Hal ini sejalan dengan hasil penelitian Fitriyah \& Setianingsi (2014), Siswa perempuan yang melibatkan metakognisinya dalam tahap merencanakan akan menyadari atas ketepatan langkah atau cara untuk memperoleh hasil penyelesaian yang benar.

\section{c. Melaksanakan Rencana}

Pada tahap melaksanakan rencana pemecahan masalah, PR kembali menjelaskan dengan kurang percaya diri bahkan membutuhkan waktu yang lama untuk menjawab pertanyaan dari peneliti. Menurut PR, ia telah mengerjakan soal sesuai dengan rencana yang telah dijelaskan sebelumnya. Pernyataan tersebut diperkuat dengan jawaban yang telah PR tulis sudah sesuai dengan langkah-langkah rencana yang telah direncanakan sebelumnya dan juga mampu menjawab setiap pertanyaan terkait jawaban yang ia tulis seperti darimana PR mendapat hasil jumlah kelereng andre $=15$, PR menjawab itu adalah hasil perhitungan Al-jabar $\mathrm{u}+\mathrm{y}+\mathrm{z}=55$. Adapun langkah-langkahnya setelah diperoleh persamaan al-jabar $\mathrm{u}+\mathrm{y}+\mathrm{z}=55$ kemudian setiap nilai dari variabel disubstitusikan dan dihitung sesuai dengan perhitungan persamaan linier 3 variabel dan akhirnya memperoleh jumlah kelereng Andre $=15$.

Hal ini menunjukkan PR telah menyadari dan memahami setiap langkah penyelesaian.Artinya PR telah mencapai indikator metakognisi dalam melaksanakan rencana yaitu dapat menjawab pertanyaan yang terkait dengan langkah-langkah penyelesaian masalah. Sejalan dengan hal tersebut, menurut Safitri et al., (2020), Siswa yang melibatkan metakognisinya dalam melaksanakan rencana penyelesaian, ia akan dapat memantau setiap langkah yang telah dilakukan dalam menyelesaikan masalah.

Meski kurang percaya diri, PR mengatakan bahwa dia yakin sudah melaksanakan rencana sesuai dengan rencana sebelumnya dan sudah benar.alasannya karena PR telah maelakukan perhitungan sesuai konsep matematika yang PR pakai. Hal ini menunjukkan PR telah mencapai indikator metakognisi dalam melaksanakan rencana yaitu dapat memberikan keyakinan terhadap rencana penyelesaian.Berdasarkan paparan tersebut dapat disimpulkan bahwa kemampuan metakognisi PR dalam melaksanakan rencana pemecahan masalah digunakan dengan baik karena PR memahami proses kognisinya dalam melaksanakan rencana pemecahan 
masalah. Berdasarkan hal tersebut, hasil penelitian Rahmawati (2015) menyatakan bahwa kemampuan metakognisi siswa berkemampuan matematika tinggi pada tahap pelaksanaan selalu malakukan sesuai dengan rencana dengan runtut, teliti dan meyakini bahwa pelaksanaannya benar.

Meski telah melibatkan metakognisinya, masih terdapat kesalahan pada proses perhitungan pada jawaban PR sehingga PR mendapatkan kesalahan dalam hasil akhirnya. Setelah dicermati kesalahan PR disebabkan karena PR belum memahami konsep yang PR gunakan. PR mampu mengaitkan konsep dengan soal tetapi ia kurang memahami konsep itu sendiri dalam aritian tidak mampu menggunakan rumus tersebut. Ketidak pahaman PR menjadi alasan mengapa PR tidak menuliskan setiap proses perhitungan secara utuh sehingga mengakibatkan terjadinya kesalahan. Hal ini berbeda dengan hasil penelitian yang dilakukan oleh Putri \& Susilowati (2016) yang mengatakan pada tahap melaksanakan rencana siswa perempuan cenderung melakukan hal-hal yang utuh seperti menuliskan hal-hal dalam soal serta langkah-langkah dari setiap perhitungan secara utuh sehingga tidak memerlukan kesimpulan pada setiap akhir jawaban.

Meski demikian kesalahan hanya terletak pada perhitungannya, untuk pelaksanaan pemecahan masalahnya sudah sesuai dengan rencanaya serta PR telah mencapai semua indikator kemampuan metakognisi dalam melaksanakan rencana.hal tersebut menunjukkan kemampuan metakognisi PR dalam melaksanakan rencana telah digunakan dengan baik.

d. Evaluasi

Pada tahap evaluasi, PR mengaku telah melakukan pengecekan terhadap hasil pekerjannya. Dengan penuh keyakinan PR mengatakan yakin dengan kebenaran hasil penyelesainnya. Alasannya karena PR tidak menemukan kesulitan saat mengerjakan soal dan telah sesuai dengan rencana penyelesaiannya serta telah melakukan evaluasi terhadap hasil penyelesaiannya. Adapun cara PR mengevaluasi adalah dengan cara mengecek kembali setiap langkah dari proses peyelesaian dalam artian semua yang telah PR tulis di lakukan pengecekan kembali serta perhitungan kembali. Hal tersebut menunjukkan PR menyadari akan pentingya melakukan evaluasi serta memahami cara mengevaluasi.

PR telah mencapai semua indikator metakognisi dalam tahap evaluasi yaitu dapat menjelaskankeyakinannya tentang hasil penyelesaian, dapat menjelaskan rencana untuk memeriksa kembali dan dapat menjelaskan ada atau tidaknya cara memeriksa kembali. Karena PR dapat mencapai semua indikator metakognisi dalam tahap evaluasi maka PR dapat dikatakan telah melibatkan metakognisinya dalam mengevaluasi. Hal ini sejalan dengan hasil penelitian 
Wahyuningtyas et al., (2019), siswa perempuan dapat memenuhi semua indikator metakognisi pada tahap perencanaan.

Terlepas dari pembahasan kemampuan metakognisi dalam tahap evaluasi, pada tahap evaluasi PR kurang teliti sehingga menyebabkan PR tidak menemukan kesalahan yang PR lakukan dalam proses pengerjaannya. Padahal menurut Putri \& Susilowati (2016) siswa perempuan lebih unggul dalam hal ketepatan, kecermatan, ketelitian dan keseksamaan berpikir dalam pemecahan masalah. Pendapat Putri \& Susilowati (2016) berbeda dengan hasil penelitian ini, sehingga diperlukan adanya penelitian lebih lanjut terhadap bagaimana kemampuan siswa perempuan dalam pemecahan masalah karena dalam penelitian ini hanya berfokus pada kemampuan metakognisi.

Dari pemaparan diatas, dapat disimpulkan bahwa PR telah memenuhi setiap indikator dari kemampuan metakognisi dalam setiap tahap pemecahan masalah. Hal ini sejalan dengan hasil penelitian Syamsuriyawati et al.,(2021), subjek penelitian berkemampuan tinggi dapat memenuhi semua indidkator metakognisi dalam pemecahan masalah. Karena telah memenuhi semua indikator metakognisi dalam pemecahan masalah maka PR telah melibatkan kemampuan metakognisi-nya dalam pemecahan masalah.

Pada hakikatnya indikator kemampuan metakognisi adalah kesadaran terhadap proses berpikir. Ketika seseoarang menyadari maka akan mampu menjelaskan begitupun sebalikya. Karena PR telah mampu menjelaskan maka PR telah menyadari sehingga dapat dikatakan bahwa PR telah melibatkan kemampuan metakognisinya dalam pemecahan masalah. Hal ini sejalan dengan pendapat Chairani (2016) yang menyatakan dasar dari kemampuan metakognisi merupakan kesadaran terhadap proses kognisinya sendiri.

\section{Subjek Penelitian Siswa Laki-laki (LK)}

Hasil analisis data dari hasil pengerjaan soal TIMSS dan wawancara menunjukkan bahwa LK telah melibatkan kemampuan metakognisinya dalam setiap langkah pemecahan masalah. Hal ini dapat dilihat pada saat wawancara LK mampu menjelaskan seluruh proses pemikirannya dalam menyelesaikan soal serta kesesuaian penjelasan PR dengan jawaban yang telah LK tulis. Selanjutnya kemampuan metakognisi LK dalam pemecahan masalah akan dibahas berdasarkan tahap-tahap pemecahan masalah yaitu sebagai berikut :

a. Memahami Masalah

Pada tahap memahami masalah LK telah berhasil memahami masalah dengan baik.Hal ini ditunjukkan dengan kebenaran hasil identifikasi permasalahan yang ditulis LK. Menurut Khairunnisa \& Setyaningsih (2017), ketika siswa sudah dapat memahami permasalahandengan 
baik berarti siswa sudah melibatkan metakognisisnya dalam memahami masalah. Berdasarkan pendapat tersebut, maka LK telah melibatkan kemampuan metakognisinya dalam memahami masalah.

Pada saat wawancara, LK dengan penuh keyakinan menjelaskan pemahamannya terhadap soal.LK menjelaskannya dengan singkat namun jelas sehingga hanya membutuhkan waktu sebentar untuk menjelaskan pemahamnya tersebut. Hal tersebut menunjukkan bahwa tingkat efikasi diri LK tinggi. Menurut Sholihah et al. (2020), seseorang dengan efikasidiri tinggi senantiasa yakin dapat menyelesaikan persoalan yang dihadapi sehingga tidak memiliki rasa ragu.

LK mengatakan yang diketahui pada soal adalah jumlah kelereng Doni sebanyak 20 kelereng lebih banyak dari kelereng Andre, kelereng Andi setengah dari kelereng Doni dan jumlah semua kelereng 55 buah dan yang ditanyakan berapa persen jumlah kelereng Andre. LK mampu menjelaskan pemahamannya menggunakan bahasanya sendiri. Adapun dalam lembar jawaban LK menulis sebagai berikut:

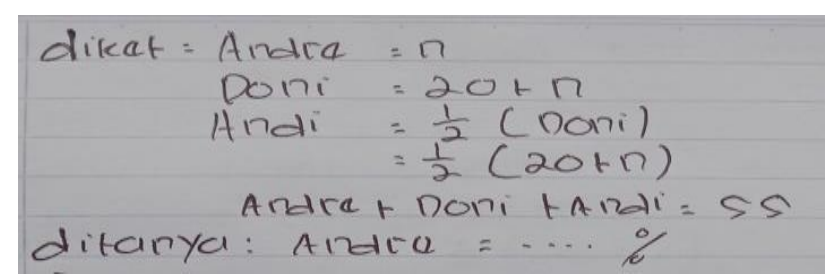

Gambar 2. Potongan Jawaban LK

Dari lembar jawaban LK pada gambar 4.12, terlihat penulisan hasil identifikasi benar dan sesuai dengan yang dijelaskan. Dari penjelasan LK menunjukkan bahwa LK telah melibatkan metakognisinya dalam memahami masalah karena ia telah memahami masalah dengan baik. Hal ini sejalan dengan pendapat Khairunnisa \& Setyaningsih (2017), ketika siswa sudah dapat memahami permasalahandengan baik berarti siswa sudah melibatkan metakognisisnya dalam memahami masalah.

Tidak hanya menjelaskan pemahamannya, LK juga menjelaskan bahwa untuk memahami masalah cukup dengan membaca sebentar saja karena baginya setiap soal terlihat jelas permasalahannya.Hal ini diperkuat dengan hasil pengamatan ketika LK mendapatkan soal, LK membutuhkan waktu sedikit untuk menuliskan hasil identifikasinya. LK telah menggunakan cara yang tepat dalam memahami masalah karena menurut Sari et al., (2016) tujuan membaca soal atau masalah adalah untuk memperoleh informasi yang dibutuhkan agar menemukan carapenyelesaian. 
LK menyadari proses berpikirnya tentang cara yang digunakan dalam memahami masalah. Hal ini menunjukkan LK telah mencapai indikator metakognisi pada tahap memahami masalah yaitu dapat menjelaskan cara -cara yang digunakan untuk memahami masalah. Hal tersebut sejalan dengan, hasil penelitian Sudia (2014), Subjek laki-laki menyadari pentingnya memikirkan cara memahami masalah, yaitu dilakukan dengan cara membaca masalah beberapa kali sampai masalah benar-benar dipahami dengan baik, Hal ini menunjukkan subjek laki-laki telah melibatkan metakognisinya dalam memahami masalah.

Selanjutnya LK memberikan alasan mengapa memilih membaca sebagai cara memahami masalah yaitu karena sudah menjadi kebiasaan LK dalam memahami masalah pada setiap soal yang ia kerjakan. Hal ini menunjukkan bahwa LK telah menyadari alasan memilih cara dalam memahami masalah. Artinya LK telah mencapai indikator metakognisi dalam memahami masalah yaitu menjelaskan alasan dalam memilih cara untuk memahami masalah. Selain itu LK juga mengatakan karena cara tersebut sudah menjadi kebiasaannya, maka LK tidak memiliki cara lain. Pernyataan tersebut menunjukkan LK telah menyadari tentang mengapa LK tidak menggunakan cara lain dalam memahami masalah. Hal ini menunjukkan LK telah mencapai indikator metakognisi dalam memahami masalah yaitu dapat menjelaskan alasan mengapa tidak menggunkan cara lain dalam memahami masalah.

Setelah memahami soal, kemudian LK mengidentifiksi permasalahan dalam soal dengan cara menyimpulkan hasil pemahamannya. LK hanya menggunakan cara tersebut karena menurut LK jika sudah paham terhadap permasalahan pada soal maka identifikasi masalah sudah jelas terlihat dalam soal sehingga LK dengan mudah mengidentifikasi permasalahannya. Hal ini menunjukkan bahwa LK menyadari pentingnya mengetahui cara meng-identifikasi permasalahan dalam soal. Dimana hal tersebut menunjukkan bahwa LK telah mencapai indikator metakognisi dalam memahami masalah yaitu dapat menjelaskan bagaimana caranya mengidentifikasi data dalam diketahui dan ditanyakan sebagai bukti bahwa siswa telah memahami masalah.

Berdasarkan penjelasan tersebut, dapat disimpulkan bahwa PR telah mencapai semua indikator metakognisi dalam memahami masalah yang digunakan dalam penelitian ini.Sehingga PR dapat dikatakan telah melibatkan kemampuan metakognisinya dalam memahami masalah. Sejalan dengan hal tersebut, menurut Sari et al., (2016) aktivitas metakognisi siswa laki-laki dalam memahami masalah berhubungan dengan pengetahuan strategi dalam memahami masalah.

b. Merencanakan Pemecahan Masalah 
Pada tahap merencanakan penyelesaian pemecahan masalah, LK menjelaskan dengan lancar dan dengan percaya diri bahwa dia akan menggunakan konsep persamaan linier tiga variabel. Adapun langkah pertama yang akan dilakukan adalah memisalkan semua yang diketahui dan yang ditanyakan, LK memisalkan Andre $=\mathrm{a}$, Doni $=\mathrm{b}$ dan Andi $=\mathrm{c}$, kemudian a $=\mathrm{n}, \mathrm{b}=20+\mathrm{n}, \mathrm{c}=1 / 2(20+\mathrm{n})$ dan $\mathrm{a}+\mathrm{b}+\mathrm{c}=55$. Adapun yang ditanyakan adalah jumlah kelereng andre $\mathrm{c}=\ldots \%$. Kemudian menjelaskan rumus dari konsep matematika yang akan LK gunakan yaitu perhitungan persamaan linier tiga variabel dengan rumus $\mathrm{a}+\mathrm{b}+\mathrm{c}=55$. Dan kemudian mencari persentase jumlah kelereng Andre dengan menggunakan rumus persentase.

Hal tersebut menunjukkan bahwa LK sudah mampu menyajikan masalah kedalam konsep matematika. Dari penjelasan LK terlihat dia telah menyadari pentingnya memikirkan rencana pemecahan masalah dan memahami konsep yang akan digunakan dalam memahami masalah. Hal ini menunjukkan bahwa LK telah mencapai indikator kemampuan metakognisi dalam memikirkan rencana yaitu dapat menjelaskan konsep-konsep yang digunakan untuk menyelesaikan masalah serta langkah-langkahnya. Hal ini sejalan dengan hasil penelitian Sudia (2014), Subjek laki-laki telah melibatkan metakognisinya karena telah mampu memikirkan rencana alur pemecahan masalah, memikirkan rumus dan waktu yang akan digunakan dalam memecahan masalah serta memikirkan cara memecahkan masalah.

Selanjutnya LK juga menjelaskan alasanya mengapa memilih rencana pemecahan masalah tersebut yaitu karena sesuai dengan pengetahuan dan pemahaman yang LK miliki tentang permasalahan dalam soal sehingga rencana itulah yang dipilih. LK juga mengatakan bahwa ia yakin rencananya akan bisa dilaksanakan dan akan mendapatkan hasil penyelesaian yang benar. Penjelasan LK menunjukkan bahwa LK menyadari tentang alasan memilih rencana dan keyakinannya terhadap rencana. Artinya LK telah mencapai indikator kemampuan metakognisi dalam memikirkan rencana pemecahan masalah yaitu dapat menjelaskan alasan dalam memilih rencana penyelesaian dan dapat menjelaskan pernyataan atau alasan tentang keyakinan dari rencana yang dibuatnya.

Berdasarkan pemaparan diatas, terlihat LK memiliki kesadaran terhadap pengetahuan yang dimiliki dan mampu mengaitkannya terhadap soal sehingnga LK mampu menuliskan serta menjelaskan langkah-langkah penyelesaian yang akan digunakan. Kesadaran tersebut merupakan aktivitas metakognisi dalam merencanakan pemecahan masalah. Hal ini sejalan dengan pendapat Sari et al., (2016), Aktivitasmetakognisi siswa laki-laki dalam tahapan menentukan rencanaadalah berhubungan dengan pengetahuan prosedural yang dimiliki siswa 
terhadap soal denganmengungkapkan langkah-langkah pengerjaan yang akan dilakukan dengan melihat soalyang diberikan.

Dari pemaparan diatas diperoleh kesimpulan bahwa kemampuan metakognisi LK dalam merencanakan pemecahan masalah sudah digunakan dengan baik. Hal ini sejalan dengan hasil penelitian Fitriyah \& Setianingsi (2014), Siswa laki-laki yang melibatkan metakognisinya dalam tahap merencanakan akan menyadari atas ketepatan langkah atau cara untuk memperoleh hasil penyelesaian yang benar.

c. Melaksanakan Rencana

Pada tahap melaksanakan rencana pemecahan masalah, LK dengan percaya diri menjelaskan bahwa ia telah melaksanakan rencananya sesuai dengan rencana awal. Pernyataan tersebut diperkuat dengan jawaban yang telah LK tulis sudah sesuai dengan langkah-langkah rencana yang telah direncanakan sebelumnya. LK juga mampu menjawab setiap pertanyaan terkait jawaban yang ia tulis seperti darimana LK mendapat hasil jumlah kelereng andre $=25 \%$, LK menjawab itu adalah hasil persentase dari jumlh kelereng andre. Adapun langkahlangkahnya setelah diperoleh jumlah kelereng Andre yaitu 10 kemudian dicari persentasenya dengan rumus $\frac{10}{55} \times 100 \%$.LK menuliskan setiap langkah penyelesaian secara utuh. Hal ini berbeda dengan hasil penelitian terdahulu yaitu penelitian yang dilakukan oleh Putri \& Susilowati (2016). Adapun hasil penelitiannya menyebutkan pada tahap melaksanakan rencana, siswa laki-laki cenderung membuat hal-hal yang simpel.

Hal ini menunjukkan LK telah menyadari dan memahami setiap langkah penyelesaian.Artinya LK telah mencapai indikator metakognisi dalam melaksanakan rencana yaitu dapat menjawab pertanyaan yang terkait dengan langkah-langkah penyelesaian masalah. Sejalan dengan hal tersebut, menurut Safitri et al., (2020), Siswa yang melibatkan metakognisinya dalam melaksanakan rencana penyelesaian, ia akan dapat memantau setiap langkah yang telah dilakukan dalam menyelesaikan masalah.

LK mengatakan bahwa dia yakin sudah melaksanakan rencana sesuai dengan rencana sebelumnya dan sudah benar.Alasannya karena LK telah maelakukan perhitungan sesuai konsep matematika yang LK pakai.Hal ini menunjukkan LK telah mencapai indikator metakognisi dalam melaksanakan rencana yaitu dapat memberikan keyakinan terhadap rencana penyelesaian.Berdasarkan paparan tersebut dapat disimpulkan bahwa kemampuan metakognisi LK dalam melaksanakan rencana pemecahan masalah digunakan dengan baik karena LK memahami proses kognisinya dalam melaksanakan rencana pemecahan masalah. Berdasarkan 
hal tersebut, hasil penelitian Rahmawati (2015) menyatakan bahwa kemampuan metakognisi siswa berkemampuan matematika tinggi pada tahap pelaksanaan selalu malakukan sesuai dengan rencana dengan runtut, teliti dan meyakini bahwa pelaksanaannya benar.

d. Evaluasi

Pada tahap evaluasi, dengan penuh keyakinan LK mengatakan bahwa hasil penyelesaiannya benar. Alasannya karena LK telah melakukan evaluasi berkali-kali dengan cara menghitungnya kembali. Pada saat melakukan evaluasi LK mengatakan keyakinannya terhadap kebenaran solusi dengan tegas. Hal ini sejalan dengan hasil penelitian Putri \& Susilowati (2016), pada tahap pengecekan kembali, siswa lakilakimemberikan keyakinan atas jawabannya dengantegas bahwa jawaban yang sudah diperoleh adalah benar. Adapun cara LK mengevaluasi adalah dengan cara mengecek kembali setiap langkah dari proses peyelesaian. Hal tersebut menunjukkan LK menyadari akan pentingya melakukan evaluasi serta memahami cara mengevaluasi.

LK telah mencapai semua indikator metakognisi dalam tahap evaluasi yaitu dapat menjelaskankeyakinannya tentang hasil penyelesaian, dapat menjelaskan rencana untuk memeriksa kembali dan dapat menjelaskan ada atau tidaknya cara memeriksa kembali. Karena LK dapat mencapai semua indikator metakognisi dalam tahap evaluasi maka LK dapat dikatakan telah melibatkan metakognisinya dalam mengevaluasi. Hal ini sejalan dengan hasil penelitian Wahyuningtyas et al., (2019), siswa laki-laki dapat memenuhi semua indikator metakognisi pada tahap evaluasi.

Dari pemaparan diatas, dapat disimpulkan bahwa LK telah mencapai semua indikator metakognisi dalam pemecahan masalah pada penelitian ini. Hal ini sejalan dengan hasil penelitian Mayasari et al., (2019), Siswa bertipe koleris memenuhi semua indikator metakognisi pada semua tahap pemecahan masalah. LK menyadari dan memahami proses berpikirnya dalam pemecahan masalah. Karena dengan kesadaran dan pemahaman itulah yang membuat LK bisa menjelaskan proses berpikirnya. Hal ini menunjukkan LK telah melibatkan kemampuan metakognisinya dalam pemecahan masalah. Pernyataan ini didasarkan pada pendapat Chairani (2016) yang menyatakan dasar dari kemampuan metakognisi merupakan kesadaran terhadap proses kognisinya sendiri.

Hasil penelitian terhadap LK pada penelitian ini menjadi penemuan baru karena berbeda dengan hasil penelitian terdahulu. Seperti hasil penelitian Khairunnisa \& Setyaningsih (2017) yang mengatakan proses metakognisi belum digunakan dengan baik oleh siswa laki-laki. perbedaan ini menjadi hal yang menarik untuk dijadikan penelitian sehingga nantinya akan 
diperoleh penemuan-penemuan baru tentang bagaimana kemampuan metakognisi siswa lakilaki dalam pemecahan masalah.

\section{SIMPULAN}

Berdasarkan hasil dan pembahasan, dapat disimpulkan bahwa siswa perempuan telah mencapai semua indikator kemampuan metakognisi dalam pemecahan masalah meliputi kesadaran terhadap proses dan hasil berpikirnya dalam memahami masalah, merencanakan pemecahan masalah, melaksanakan rencana pemecahan masalah dan mengevaluasi. Siswa lakilaki juga telah mencapai juga telah mecapai semua indikator kemampuan metakognisi dalam pemecahan masalah meliputi kesadaran terhadap proses dan hasil berpikirnya dalam memahami masalah, merencanakan pemecahan masalah, melaksanakan rencana pemecahan masalah dan mengevaluasi. Hal tersebut menunjukkan bahwa tidak ada perbedaan kemampuan metakognisi dalam pemecahan masalah antara siswa laki-laki dan siswa perempuan.Kemampuan metakognisi siswa laki-laki dan siswa perempuan telah digunakan dengan baik dalam pemecahan masalah.

\section{UCAPAN TERIMA KASIH}

Terimakasih saya ucapkan kepada bapak Ahmas Musaddad, S.Pd., selaku kepala sekolah SMP Al-Falah, Pesanggrahan yang telah berkenan memberikan izin untuk dilakukan penelitian. Serta terimakasih saya ucapkan kepada dosen pembimbing bapak Zainul Munawwir, M.Pd dan ibu Lisma Dian Kartika Sari, M.Si.

\section{DAFTAR RUJUKAN}

Akbar, P., Hamid, A., Bernard, M., \& Sugandi, A. I. (2018). Analisis Kemampuan Pemecahan Masalah Dan Disposisi Matematik Siswa Kelas Xi Sma Putra Juang Dalam Materi Peluang. Journal Cendekia: Jurnal Pendidikan Matematika, 2(1), 144-153.

Amir, Z. (2013). Perspektif gender dalam pembelajaran matematika. Marwah, XII(1), 14-31.

Anderson, L. W., \& Krathwohl, D. R. (2010). Kerangka landasan untuk pembelajaran, pengajaran, dan asesmen: revisi taksonomi Bloom. (Terjemahan Agung Prihantoro). NY: Pearson AddisonWesley.

Anggo, M., Salam, M., Suhar, \& Satri, Y. (2014). Strategi Metakognisi untuk Meningkatkan Hasil Belajar Matematika Siswa. Jurnal Mtematika, 5(1), 81-88.

Anggraeni, R., \& Herdiman, I. (2018). Kemampuan Pemecahan Masalah Matematik Siswa Smp Pada Materi Lingkaran Berbentuk Soal Kontekstual Ditinjau Dari Gender. Jurnal Numeracy, 5(April), $19-28$.

Asnafiyah. (2020). Analisis Kemampuan Pemecahan Masalah Dalam Menyelesaikan Soal Uraian Tingkatan Higher Order Thinking Skills (Hots). Fakultas Keguruan Dan Ilmu Pendidikan Universitas Pancasakti Tegal. 
365 | Jurnal Pendidikan dan Kewirausahaan Vol. 9 No. 22021

Chairani, Z. (2016). Metakognisi Siswa dalam Pemecahan Masalah Matematika. CV Budi Utama.

Fitriyah, I., \& Setianingsi, R. (2014). Metakognisi Siswa Smp Dalam Menyelesaikan Soal Cerita Ditinjau Dari Kemampuan Matematika Dan Gender. MATHEdunesa Jurnal Ilmiah Pendidikan Matematika, 3(3), 120-124.

Hermawan, I. (2019). Metodologi Penelitian Pendidikan ( Kualitatif, Kuantitatif dan Mixed Method ). In Hidayatul Quran (p. 200).

Iswahyudi, G. (2012). Aktivitas Metakognisi Dalam Memecahkan Masalah Pembuktian Langsung Ditinjau Dari Gender Dan Kemampuan Matematika. Seminar Nasional Program Studi Pendidikan Matematika UNS Surakarta, 1-19.

Jianto, Anita, \& Boisandi. (2020). Pengaruh Penerapan Lembar Kerja Siswa Berbasis Inkuiri Terbimbing Terhadap Kemampuan Metakognisi Siswa Pada Materi Hukum II Newton. RADIASI: Jurnal Berkala Pendidikan Fisika, 13(2), 61-64.

Khairunnisa, R., \& Setyaningsih, N. (2017). Analisis Metakognisi Siswa Dalam Pemecahan Masalah Aritmatika Sosial Ditinjau Dari Perbedaan Gender. Konferensi Nasional Penelitian Matematika Dan Pembelajarannya II, Knpmp Ii, 465-474.

Mayasari, D., Utomo, D. P., \& Cholily, Y. M. (2019). Analisis Metakognisi Siswa Dalam Memecahkan Masalah Matematika Ditinjau Dari Tipe Kepribadian Hipocrates. Jurnal Kajian Pembelajaran Matematika, 3(April), 34-39.

Netriwati. (2016). Analisis Kemampuan Pemecahan Masalah Matematika Berdasarkan Teori Polya Ditinjau Dari Pengetahuan Awal Mahasiswa Iain Raden Intan Lampung Al-Jabar. Jurnal Pendidikan Matematika, 7(2), 181- 190.

Prabawa, E. A., \& Zaenuri. (2017). Analisis Kemampuan Pemecahan Masalah Ditinjau Dari Gaya Kognitif Siswa pada Model Project Based Learning Bernuansa Etnomatematika. Unnes Journal of Mathematics Education Research, 6(1), 120-129.

Putri, J., \& Susilowati, A. (2016). Profil penalaran siswa smp dalam pemecahan masalah matematika ditinjau dari perbedaan gender. 1(2), 132-148.

Rahmawati, K. D. (2016). Analisis Kemampuan Metakognisi Siswa Dalam Menyelesaikan Soal Cerita Matematika Berbasis Polya Subpokok Bahasan Plsv Kelas VII-A SMP Negeri 3 Jember.

Safitri, P. T., Yasintasari, E., Putri, S. A., \& Hasanah, U. (2020). Analisis Kemampuan Metakognisi Siswa dalam Memecahkan Masalah Matematika Model PISA Pendidikan merupakan media. Journal of Medives : Journal of Mathematics Education IKIP Veteran Semarang, 4(1), 11-21.

Sari, R., Kusmayadi, T. A., \& Sujadi, I. (2016). Masalah Matematika Ditinjau Dari Gender Siswa Kelas Vii Smp Negeri 1 Nanggulan. 4(5), 496-509.

Sholihah, I., Munawwir, Z., \& Noervadila, I. (2020). Analisis Efikasi Diri Dalam Pemecahan Masalah Matematis Peserta Didik Kelas XI MA Darul Ulum. Jurnal Pendidikan Dan Kewirausahaan, 8(1), 66-76.

Sudia, M. (2014). Profil Metakognisi Siswa SMP Dalam Memecahkan Masalah Terbuka Ditinjau dari Perbedaan Gender. 5(1973).

Sudia, M. (2015). Profi Metakognisi Siswa SMP dalam Memecahkan Masalah Terbuka Ditinjau dari Perbedaan Gender. Jurnal Pendidikan Dan Pembelajaran, 22(1), 17-24.

Sugiarmin, M., \& Heryati, E. (2009). Konsep Dasar Hambatan Dan Proses Kognisi Kaitannya Dengan 
Sensori, Persepsi, Dan Memori. Fakultas Ilmu Pendidikan Universitas Pendidikan Indonesia.

Syamsuriyawati, Rahmawati, \& Nirfayanti. (2021). Kemampuan Metakognisi dalam Pemecahan Masalah Matematika Siswa Kelas VIII.A SMP Hang Tuah Makassar. JURNAL ILMIAH PENDIDIKAN MATEMATIKA, 4(1), 60-66.

Utami, R. W., \& Wutsqa, D. U. (2017). Analisis Kemampuan Pemecahan Masalah Matematika dan Self-Efficacy Siswa SMP Negeri di Kabupaten Ciamis. Jurnal Riset Pendidikan Matematika, 4(2), 166-175.

Wahid, A. H. (2018). Integrasi Higher Order Thinking Skill ( HOTS ) Dengan Model Creative Problem Solving. MODELING: Jurnal Program Studi PGMI, 5(1), 82-98.

Wahyuningtyas, D. A., Sugiarti, T., \& Murtikusuma, R. P. (2019). Profil metakognisi dalam menyelesaikan soal cerita ditinjau dari kemampuan matematika dan gender. JP2M (Jurnal Pendidikan Dan Pembelajaran Matematika), 5(1), 6-12.

Weni, R., Herlina, E., \& Nari, No. (2019). Analisis Kemampuan Metakognisi Siswa Dalam Memecahkan Masalah Matematis Di SMPN 3 X Koto Singgalang Kabupaten Tanah Datar Ditinjau Dari Gender. Jurnal Agenda, 2(1). 